\title{
Quality of Land Fertility on Post Cement Mine Areas in South Kalimantan, Indonesia
}

\author{
Yudi Firmanul Arifin ${ }^{1,2, *}$, Siti Hamidah ${ }^{1,2}$, Gusti Muhammad Hatta ${ }^{1,2}$, Fachrur Razie ${ }^{3}$ \\ ${ }^{1}$ Faculty of Forestry, Lambung Mangkurat University, Indonesia \\ ${ }^{2}$ Consortium Research for Sustainable Tropical Forest Management, Indonesia \\ ${ }^{3}$ Faculty of Agriculture, Lambung Mangkurat University, Indonesia
}

Copyright $\subset 2018$ by authors, all rights reserved. Authors agree that this article remains permanently open access under the terms of the Creative Commons Attribution License 4.0 International License

\begin{abstract}
Cement mining activities PT. Indocement Tunggal Prakarsa (PT.ITP) in Tarjun Kotabaru has partly entered the post-operative stage and it is being prepared for revegetation. To restore the level of fertility of land according to the standards required to be revegetated with the species of plants belonging to fast-growing species. In order for successful planting activities it is necessary to know the level of fertility. The types of soil can be found in the study area included; clay, laterite, and lime-stone. This collecting of sample uses a purposive sampling method, in which sample points are placed on each soil type. The result showed that soil fertility level is relatively low with C-organic, $\mathrm{P}_{2} \mathrm{O}_{5}, \mathrm{~K}_{2} \mathrm{O}, \mathrm{CEC}$, and basic saturation parameters under secondary natural forest condition so that fertilizer addition is needed in each type of land to increase fertility.
\end{abstract}

Keywords Land, Post Mining, Fertility, Revegetation

\section{Introduction}

The common problem with ex-mining areas is environmental change. Change chemically primarily impacting groundwater and surface water, continues physically morphological changes and land topography. Furthermore, it is a microclimate change due to changes in wind speed, disturbance of biological habitat in the form of flora and fauna, and decreased productivity of land with the consequences of being barren or bare. Based on the change needs to be done reclamation effort. Besides aiming to prevent erosion or reducing runoff water flow rate, reclamation is done to keep the land unstable and more productive. Reclamation is expected to generate added value for the environment and creating a much better state than the previous situation. $[27,19,18]$

Open pit mining in South Kalimantan causes such problems as Soil quality will decrease drastically, decline in quality or quality of soil may occur physically, and chemical and biological. The soil will lose the surface of the topsoil and the resultant compaction heavy equipment activity, changes in soil chemical content $(\mathrm{pH}$, chemical components) are extreme, loss some micro elements, the loss of soil organisms (biodiversity) so that the pores of the soil changed $[31,25]$. Under natural conditions of nature can repair this damage takes a very long time therefore it is necessary to intervene in the rehabilitation process. A common strategy for restoring land is to improve quality land, choosing the right seeds, seeding, planting and maintenance. Rehabilitation is an integrated and time-consuming process.

The problem is the effort of revegetation in the post-mining land, it is not easy this is constrained by land conditions that are marginal status, causing slow-growing plants, growth languish, dwarf and often become the cause of death. In order for the implementation of revegetation to produce normal plant growth as well as sustainable growth, knowing and understanding the marginal post-mining land conditions and knowing how to improve them is known.

Mining activities of cement for raw materials PT. Indocement Tunggal Prakarsa (PT ITP) in the Tarjun Region of Kotabaru Regency has partially entered the post-mining phase and it is preparing for reclamation and revegetation. Plants are important components of ecosystems, they are the primary food producers and therefore it is important to identify the magnitude of the toxid effects on these organism [7]. Post-mining activities efforts have also been implemented in accordance with the environmental management plan as contained in the Environmental Impact Analysis document, in particular the Environmental Management Plan, approved by the Central AMDAL Appraisal Commission.

The types of land contained in the mining area of PT. ITP included; laterite, clay, and limestone. These soil types are poor nutrients and efforts need to improve their fertility. 
Mining and processing of zinc-lead ores are activities that can enrich surrounding area with heavy metals [21]. The adverse effects of heavy metals in some areas are connected with their transfer in the trophic chain, from soil through plants to animal and human [23]. Metal is associeted with contaminated groundwater and soils [1]. The chemical analyses are seldom suited for the evaluation of potential ecology risks $[6,2]$. The first stage that needs to be done to determine the level of fertility, namely by testing the soil samples in the laboratory.

This study aims to determine the level of critical land in the area of cement mining PT. ITP as a first step to plan the planting will be done. This method is expected to increase the success rate of the planting. Good planning and environmenal management will minimiza the umpacts of mining on the environment and will help in preserving eco-diversity. This article want to assess the deterioration of physical and chemical soil properties due to surface mining and also their management with a purpose to get productive mine soil.

\section{Materials and Methods}

\section{Study Location}

The study was conducted in the cement mining area of PT. ITP in Tarjun Sub-district, Kotabaru Regency, South Kalimantan Province. Types of soil found in this area consist of laterite, clay, and lime-stone. These materials used as source for making cement. These areas are quite open, so erosion and leaching as well are very high.

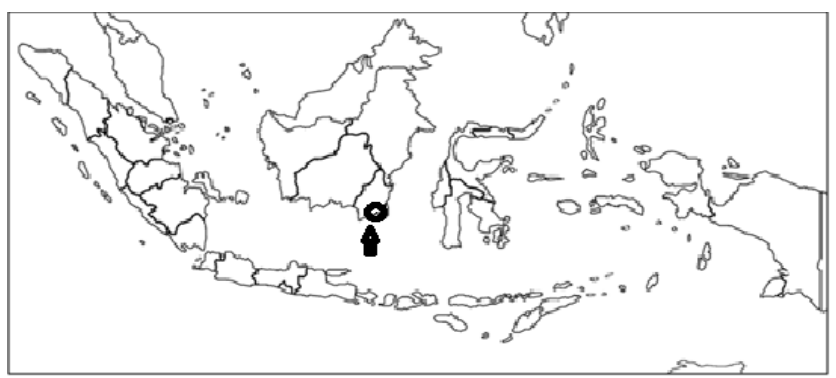

Picture 1. Location of research

\section{Soil Analyses}

$A s$ an assessment standard for soil fertility degree, ie soil texture (sand, dust and clay), soil permeability, bulk density, density particles, porosity, soil acidity $(\mathrm{pH})$, soil nutrients $\mathrm{N}, \mathrm{P}, \mathrm{K}, \mathrm{C}$-org, $\mathrm{Ca}, \mathrm{Mg}, \mathrm{Na}, \mathrm{Al}, \mathrm{KB}$, and Cation Exchange Capacity (CEC).

This research begins with preparation. The method used in this research is descriptive survey method with sampling by purposive sampling according to soil type (laterite, clay and limestone). In general, research conducted on 4 (four) stages, namely: (1) preparation, (2) field implementation,
(3) laboratory analysis, and (4) aata analysis / discussion.

The preparation stage includes the preparation of field survey equipment. Required equipment such as a ground drill, sample ring and equipment and other materials. Field implementation stage is the activity of soil sampling. Soil sampling is carried out in PT. ITP, there are three types of soil studied in this research, namely on Lateritic land, clay / clay and Lime stone. In each land area two composite soil samples were taken at a depth of $0-20 \mathrm{~cm}$. At each sample point, soil samples were taken in a disturbed condition using a soil drill and which were not disturbed using the sample ring.

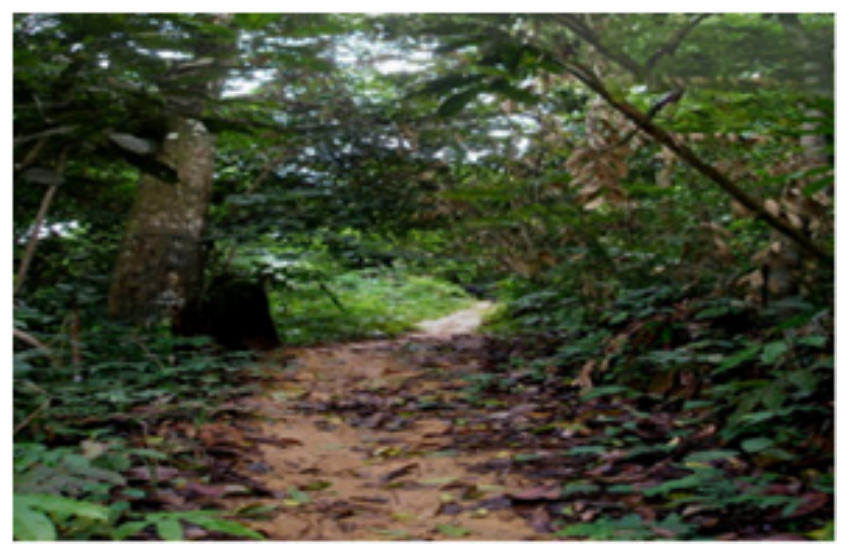

Picture 2. Secondary forest land (control)

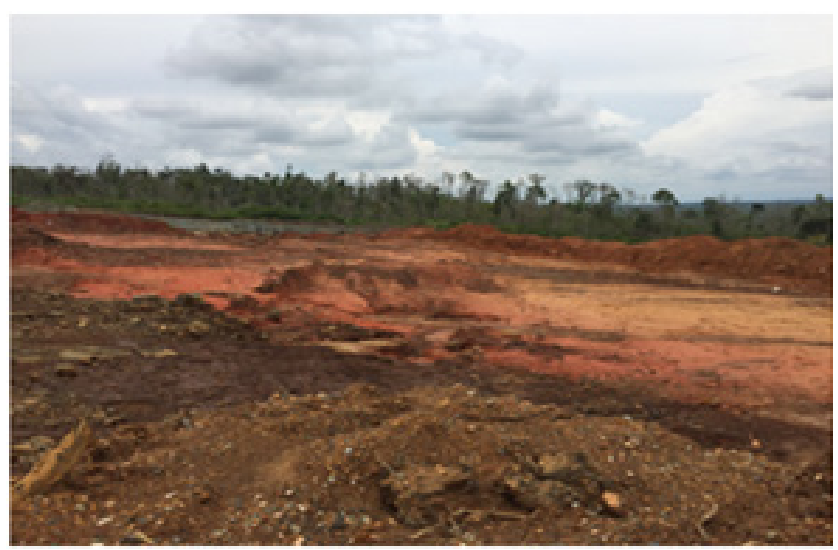

Picture 3. Laterite land

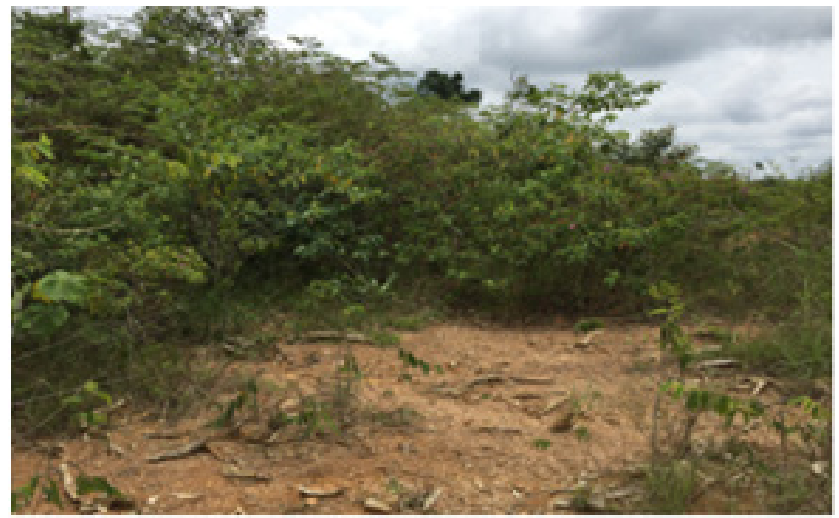

Picture 4. Clay land 


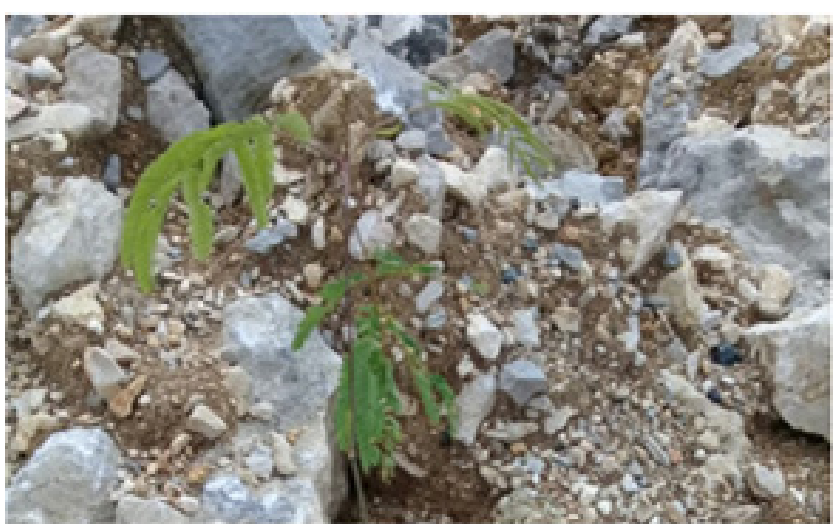

Picture 5. Lime-stone land

The stage of laboratory analysis is carried out in Soil Fertility laboratory Faculty of Agriculture Universitas Lambung Mangkurat. The disturbed soil samples were dried and sieved using a $2 \mathrm{~mm}$ sieve, while the undisturbed soil samples were directly weighed for soil weight and then partially filled with water to analyze some soil physical properties. The soil physical properties variables analyzed are as follows: Soil texture (fraction of dust, sand and clay) using pipette method, Porosity determined from Bulk Density determination using ring sample and Particle Density using pixometer with gravimetric method, and soil permeability using Constant Head Permeameter. The calculation of the porosity value of the soil follows the formula: Porosity $=(1-\mathrm{BD} / \mathrm{PD}) \times 100 \%$. Furthermore, the soil chemical properties analyzed were $\mathrm{P}$ and $\mathrm{K}$ total using the method of degradation with $25 \% \mathrm{HCl}$ extract, total $\mathrm{N}$ using Kjeldhal macro method, C-organic extracted K-Chromate using Walkley and Black method, P-available using Bray I extract spectrophotometer method, $\mathrm{pH} \mathrm{H}_{2} \mathrm{O}$ (1: 2,5), interchangeable cations and Soil Cation Exchange Capacity extracted extract with $\mathrm{NH}_{4} \mathrm{OAc} 1 \mathrm{M} \mathrm{pH} 7.0$ and interchangeable $\mathrm{Al}$ is extracted with $1 \mathrm{~N} \mathrm{KCl}$ using titrimetric method.

The last step is to analyze the physical and chemical properties of the soil and discuss it descriptively to know and study the soil chemical status and soil fertility. Assessment of soil chemical status using criterion of soil chemical properties based on criteria issued by Soil
Research Institute in 1983. While soil fertility status was determined using soil fertility criterion assessment of fertility status based on criteria of Soil Research Center in 1995.

\section{Results}

\subsection{Assessment of Soil Physical Properties}

Some of the physical properties of the soil have a role in forming the land, such as texture, permeability and porosity. Relative amount of sand (2.0-0.05 mm), silt (0.05-0.002), and clay $(<0.002)$ sized particles determine the texture of soil. Mine soils with sandy textures can not hold as much water or nutrients as finer textured soils like loams and silts [26]. The result of measurement of soil physical properties is presented in Table 1 .

Soil fertility is strongly influenced by soil texture. Most pores in sandy soils are large and drain rapidly and sand particles have low cation exchange capacity compared than the others, therefore sandy soils have low nutrient and water retention capacity [29]. The texture of the soil found in post-cement mine of PT. ITP land on laterite soil is silt clay loam, clay ranges from clay loam to clay, while in lime stone clay ranges from sandy clay loam to clay. Clay particles have a high cation exchange capacity can therefore hold nutrients and organic matter [10]. Organic matter accumulates in clay-rich soils because it is poorly accessible to decomposing microbes by binding to clay particles and occlusion within aggregates [3, 23]. This condition is supported by the rapid difference of permeability of the three types of land present in PT. ITP, in quick succession of Laterite, clay to lime stone soil. However, in contrast to the permeability, the porosity of the three soil types decreases from laterite, clay to lime stone. Porosity in Laterite soils is higher than clay and lime stone soils, but permeability is lower when compared to both types of soil. This condition indicates that the high porosity in the laterite soil is thought to contain more micro space when compared to other soil types.

Table 1. The physical properties of soil in post-cement mine areas

\begin{tabular}{|c|c|c|c|c|c|c|c|}
\hline \multicolumn{2}{|c|}{ Phisical properties } & \multicolumn{2}{|c|}{ Laterite } & \multicolumn{2}{c|}{ Clay } & \multicolumn{2}{c|}{ Lime-stone } \\
\hline \multirow{4}{*}{ Texture } & Sand (\%) & 14,28 & 7,98 & 19,09 & 34,37 & 45,77 & 33,40 \\
\cline { 2 - 9 } & Silt (\%) & 52,37 & 61,32 & 37,35 & 33,34 & 27,08 & 41,14 \\
\cline { 2 - 9 } & Clay (\%) & 33,35 & 30,71 & 43,56 & 32,28 & 27,15 & 25,46 \\
\cline { 2 - 9 } & Class & Silt clay loam & Silt clay loam & clay & Clay loam & Sandy clay loam & loam \\
\hline \multicolumn{2}{|c|}{ Permeability (cm/hour) } & 0,34 & 0,40 & 1,16 & 1,53 & 4,83 & 2,82 \\
\hline \multicolumn{2}{|c|}{ Porosity (\%) } & 48,08 & 47,07 & 44,89 & 33,45 & 22,54 & 23,55 \\
\hline
\end{tabular}


Lime stone has higher sand included sandy clay loam which it is higher permeability ( $\mathrm{cm} /$ hour) compared than both soil types. Sandy soils have a low capacity to store C. Water infiltration into sandy soil may be reduced by water repellency $[16,21]$.

\subsection{Soil Chemistry}

\subsubsection{Soil $\mathrm{pH}$}

Soil $\mathrm{pH}$ is a measure of active soil acidity and is the most commonly used indicator of mine soil quality. The $\mathrm{pH}$ of a given mine soil can change rapidly as the rock fragments weather and oxidize. Phyritic minerals $\left(\mathrm{FeS}_{2}\right)$, when present, oxidized to sulfiric acid and drastically lower the $\mathrm{pH}$, while carbonate $\left(\mathrm{Ca} / \mathrm{MgCO}_{3}\right)$ bearing minerals and rocks tend to increase the $\mathrm{pH}$ as they weather and dissolve. Unweathered (or unoxidized) mine soils those contain a significant amount of pyritic-S in excess of their neutralizers (carbonates) will rapidly drop the $\mathrm{pH}$ to a range of 2.2-3.5 after exposure to water and oxygen [26].

Land in secondary forest has a $\mathrm{pH}$ of 5.46 while soil $\mathrm{pH}$ on cement land of PT. ITP ranges from 3.23-8.05 (Table 2), where the soil $\mathrm{pH}$ value is acid to neutral. The soils showed acid in clay and alkaline, and alkaline in limestone. If a mine soil $\mathrm{pH}$ range in the range of 6.0 to 7.5 is ideal for forages and other agronomic and horticultural uses $[12,14]$ According to Hakim et al. (1986) [8], soil reactions (pH) outside the 6-7 range may result in a decrease in the availability of certain nutrients and sometimes lead to other nutrient availability. This can result in disruption of nutrient uptake by plants thus inhibiting growth and decreasing plant productivity [30]. At neutral $\mathrm{pH}$ (6-7) nutrient availability becomes optimal in terms of nutrient quantity and equilibrium in soil solution [29].

\subsubsection{C-organic and N-total}

The $\mathrm{C}$-organic values in the study area ranged from $0.07 \%$ to $0.87 \%$ (very low-low). The lowest content of organic carbon was found in a soil sampled collected from sampling in laterite and the higest from sampling in limestone. A level of organic carbon greater than $0.75 \%$ indicates good fertility [13]. Organic carbon is positively correlated with available $\mathrm{N}$ and $\mathrm{K}$ and negatively correlated with $\mathrm{Fe}, \mathrm{Mn}, \mathrm{Cu}$, and $\mathrm{Zn}[20]$.

Nitrogen is needed by plants in large quantities, generally becoming a limiting factor on non-fertilized soils
[29]. The three major macronutrients, namely nitrogen, phosphorus and potassium are generally found to be deficient in overburden dumps [7,25]. $\mathrm{N}$ is taken root in inorganic form, ie $\mathrm{NH}_{4}^{+}$(ammonium) and $\mathrm{NO}_{3}^{-}$(nitrate) [15]. $\mathrm{NH}_{4}^{+}$absorption is more prevalent in neutral soil $\mathrm{pH}$, whereas $\mathrm{NO}_{3}{ }^{-}$at low $\mathrm{pH}$. The $\mathrm{NO}_{3}{ }^{-}$compound generally moves toward the root due to mass flow, the $\mathrm{NH}_{4}{ }^{+}$ compound is not car, the movement is caused by the diffusion also the mass flow [24]. The nitrogen content in the study area can be described as low $(0.04-0.20 \%)$. The lowet content of nitrogen was found in a soil sampled collected fromsampling in laterite and the higest from sampling in secondary forest (Table 2).

\subsubsection{Content of $\mathrm{P}_{2} \mathrm{O}_{5}$ and $\mathrm{K}_{2} \mathrm{O}$}

Organic matter is the major source of nutrients such as nitrogen, and available $\mathrm{P}$ and $\mathrm{K}$ in unfertilized soils [9]. All newly created mine soils, and many older ones, will require significant fertilizer element applications for the establishment and maintenance of any plants community.

Phosphor is a macro element which is very important for plant growth but its level is lower than $\mathrm{N}, \mathrm{K}$ and $\mathrm{Ca}$. As a growth factor, phosphorus is considered more important than $\mathrm{Ca}$ and $\mathrm{K}$ [24]. $\mathrm{P}_{2} \mathrm{O}_{5}$ and $\mathrm{K}_{2} \mathrm{O}$ values were used to assess soil fertility status according to PPT criteria (1983). The result of soil analysis also shows that the content of $\mathrm{P}_{2} \mathrm{O}_{5}$ and $\mathrm{K}_{2} \mathrm{O}$ on the land of cement area of PT. ITP of all soil samples was described very low (1.02-2.71 $\mathrm{mg} \mathrm{P}_{2} \mathrm{O}_{5}$ / $100 \mathrm{~g}$ ), while the $\mathrm{K}_{2} \mathrm{O}$ content in the sample was described as low to moderate (2.95-3.49 $\mathrm{mg} \mathrm{K}_{2} \mathrm{O} / 100 \mathrm{~g}$ ) (Table 2).

\subsubsection{Exchange Bases (K, $\mathrm{Na}, \mathrm{Ca}, \mathrm{Mg})$}

In general, $\mathrm{K}$ is usually absorbed by plants in the form of $\mathrm{K}^{+}$. Usually $\mathrm{K}$ is found in large quantities in the soil, but only a small part of the plant is used, that is water soluble or interchangeable (in soil colloids) [29]. The exchangeable bases/cations $(\mathrm{K}, \mathrm{Na}, \mathrm{Ca}, \mathrm{Mg})$ are the equivalent milligrams of each cation in the exchange complex and are cationic forms which can be absorbed by the plant.

The results showed that the Ca-exchange values in all samples ranged from very low to moderate $(2.32-2.93$ me $/ 100 \mathrm{~g}$ ); Mg-exchange values range from 0.11-0.13 me/organic $100 \mathrm{~g}$ (very low to low), Na-exchange values range from $0.01-0.03 \mathrm{me} / 100 \mathrm{~g}$ (very low), whereas the value of $\mathrm{K}$ - exchange rates ranging from 0.01 to $0.03 \mathrm{me}$ $/ 100 \mathrm{~g}$ (relatively low) (Table 2).

Table 2. Soil chemical properties on cement land of PT. ITP

\begin{tabular}{|c|c|c|c|c|c|c|c|c|c|c|c|c|c|}
\hline Tyne & $\mathrm{pH}$ & $\mathrm{SO}_{4}$ & $\mathrm{C}$ & $\mathrm{N}$ & P-total & K-total & Ca-dd & Mg-dd & Na-dd & K-dd & $\mathrm{CEC}$ & \multirow{2}{*}{ P Bray (ppm) } & \multirow{2}{*}{$\mathrm{V}(\%)$} \\
\hline $1 y_{p}$ & $\mathrm{H}_{2} \mathrm{O}$ & (ppm) & \multicolumn{2}{|c|}{----- \% ------ } & \multicolumn{2}{|c|}{$\mathrm{mg} / 100 \mathrm{~g}$} & \multicolumn{5}{|c|}{-------- me/100 g tanah -------- } & & \\
\hline Soil in Secondary Forest & 5.46 & 0.58 & 0.56 & 0.20 & 13.75 & 36.81 & 9.04 & 1.70 & 0.10 & 0.64 & 34.40 & 2.33 & 33.37 \\
\hline Laterite & 5.84 & 0.69 & 0.07 & 0.04 & 1.48 & 3.40 & 2.32 & 0.12 & 0.03 & 0.01 & 18.93 & 1.05 & 13.02 \\
\hline Clay & 3.23 & 0.66 & 0.16 & 0.06 & 1.41 & 3.23 & 2.50 & 0.12 & 0.02 & 0.02 & 20.84 & 0.82 & 12.72 \\
\hline Limestone & 8.05 & 0.66 & 0.87 & 0.06 & 2.08 & 2.96 & 9.23 & 0.11 & 0.02 & 0.02 & 21.01 & 0.75 & 44.03 \\
\hline
\end{tabular}




\subsubsection{Cation Exchange Capacity}

CEC ground depends on the type and amount of clay content, organic matter content and soil $\mathrm{pH}$. Therefore, the size of CEC is very determining the level of soil fertility [5]. The reclamation activity of the former cement mine does not cause changes in the soil CEC compared to the CEC in the non-reclaimed land (secondary forest). The CEC in all soil samples ranged from 18.93 to $34.40 \mathrm{me} / 100 \mathrm{~g}$ of soil (Table 2), which can be explained from low to very high. The soil conditions are acidic that the soil loses the cation exchange capacity and the ability to store cation nutrients in exchangeable form due to the development of positive charges [29].

\subsubsection{Base Saturation (V-value)}

Basic saturation (KB) is the ratio between the number of exchange cations with cation exchange capacity (CEC). Similar to soil CEC, the saturation of the soil base on non-reclaimed land is not unlike the reclaimed mining land. The $\mathrm{V}$-values in all soil samples ranged from very low $(12.25 \%)$ to moderate $(50.41 \%)$.

\subsubsection{Status of Soil Fertility}

Table 3. Soil fertility status in three soil types in cement mining area compared with secondary forest

\begin{tabular}{|c|c|c|c|c|c|c|c|}
\hline No. & Type of soil & C organic & P-total & K-total & CEC & V & Soil fertility \\
\hline & Soil in secondary forest & L & L & M & H & L & L \\
\hline & Laterit & L-VL & L & VL & L & L & L \\
\hline & Clay & VL & L & VL & M & L & L \\
\hline & Limestone & L-VL & L & VL & M & M & L \\
\hline
\end{tabular}

Source: primary data that is processed (2017). $\mathrm{VL}=$ very low; $\mathrm{L}=$ low; $\mathrm{M}=$ medium; $\mathrm{H}=$ high; $\mathrm{VH}=\mathrm{very}$ high

Soil fertility is the ability of the soil to provide nutrients in a sufficient and balanced condition without any toxic substances supported by water and air systems that support the growth of plants. Based on the soil fertility criteria of Soil Research Center (1983) with key parameters of soil fertility (C-organic, $\mathrm{P}_{2} \mathrm{O}_{5}, \mathrm{~K}_{2} \mathrm{O}, \mathrm{KTK}$, and saturation), fertility status in the study area is lower than non-reclaimed land (secondary forest). All soil types have the same fertility level, that is low-medium (Table 3).

In general, soil fertility in post-mining land is relatively low compared to secondary forest. The fields are generally open so that erosion and nutrient leaching occur.

\section{Discussion}

Soil texture greatly determines the water system in the soil, in the form of infiltration speed, penetration and ability to bind water by soil. Soil texture is also very strong influence on soil fertility, especially the ability to bind nutrients and affect the CEC [32]. Clay particles tend to have high CEC and have nutrient binding ability, compared to sand and dust particles.

The soil in the post-mine area of PT ITP has a fairly high variation between one sample point and the other sample points. On laterite soils have sand content of $14.28 \%$ and $7.98 \%$, silt of $52.37 \%$ and $61.32 \%$ and clay $33.35 \%$ and $30.71 \%$, from these data indicate that between the sample points there is a high enough difference for each soil texture, sand. Similarly, on clay soil with $19.09 \%$ sand and $34.37 \%$, and limestone soil with sand $45.77 \%$ and $33.40 \%$. A considerable difference between one point and another is thought to be caused by the high erosion rate, since the land in the post cement mine is generally open and tends. This condition resulted in sand washed by rain water so dissolved. In lime-stone soils the content of sand tends to be high compared to laterite and clay soil. Soil with high sand content tends to have low nutrient and CEC [32]. But in reality lime-stone has nutrient content and CEC is not too much different from laterite and clay soil. CEC soils may vary with $\mathrm{pH}$ change. The soil conditions are so acidic that the soil loses the cation exchange capacity and the ability to store cation nutrients in the form of cation exchange due to the development of positive charges [29]. Because lime-stone soil has a $\mathrm{pH}$ of 8 it tends to bind high cation and CEC cations than the other two types of soil.

In the laterite soil contains the highest silt $52.37 \%$ and $61.32 \%$ compared to clay and lime-stone. High dust content tends to have a lower soil nutrient binding ability when compared to clay soils containing higher clay. The lower clay has a low CEC. Clay particles have high CEC and can hold nutrients and organic matter $[10,17]$. Organic matter accumulates in clay-rich soils because it is poorly accessible to decomposes in aggregates [4, 23].

Clay soil certainly has a high clay content compared to the other two laterite and lime-stone land. High clay content of course has the ability to bind high soil nutrients and CEC are also high. However, when compared with lime-stone, the soil nutrient content on the clay is mostly lower. This is because lime-stone has a relatively neutral $\mathrm{pH} 8$ to make optimal soil in regulating nutrient balance in soil solution. According to [15] soils with a low $\mathrm{pH}$ or less than 6 result in a decrease in the availability of certain nutrients and sometimes even the advantages and availability of other nutrients. This resulted in disruption of nutrient uptake by plants thus inhibiting growth and decreasing plant productivity [30]. 
In general, land in the post-mining area of cement PT. ITP has a much lower nutrient content than secondary forest that is still covered by vegetation and has not been disturbed once. Although the fertility of soils in secondary forests is much higher than the three types of land present in post-mining areas of PT. ITP, but in general soil fertility in secondary forest in South Kalimantan is still relatively low according to the criteria of Soil Research Center (1983).

After knowing the low nutrient content in the three types of soil in post mining area of PT. ITP, it is necessary to determine the type of plant capable of living in the area, as well as the necessity of adding nutrients especially in the first year until the third year of planting, until the plant is able to adapt well with poor soil nutrients and low $\mathrm{pH}$ for laterite and clay soil.

Normally low pH was caused high content of metal in the soil. Metal concentrations in soil exert an enormous influence on the diversity, composition, and activity of soil microorganisms that carry out essential ecosystem services. At low concentrations, microorganisms can affect plant growth and disease through the production of metal chelators [8].

\section{Conclusions}

From the result of study on post-mining area of PT. ITP summed up as follows:

(1) Based on the soil fertility criteria of Soil Research Center (1983) with key parameters of soil fertility (C-organic, $\mathrm{P}_{2} \mathrm{O}_{5}, \mathrm{~K}_{2} \mathrm{O}$, KTK, and saturation bases, soil fertility status of post-mining land of PT ITP cement is very low to low compared to land of secondary forest.

(2) Low nutrient content in the three types of soil at the post-mining area of PT. ITP is necessary to determine the type of plant capable of living in the area, as well as the necessity of adding nutrients especially in the first year until the third year of planting.

\section{REFERENCES}

[1] Aelion CM. Darvis HT (2007). Use of general toxicity test to predict heavy metal concemtrate ionis in the residential soils.

[2] Alvarenga P. Palma P., Goncalves AP., Firnandes, RM, de Vennes A, Valini G, Duarte E, Qunha-Queda AC (2008) Evaluation of test to assess the quality of mine-contaminated soils. Environ geochem Healt 30:95-99.

[3] Baldock, J., Keyes, D., Kirk, R., Lessand, R. (2001) Interaction between organic materials and microorganisms with minerials in the stabilization of soil structure. In: Huang PM, Bollag, J.M., Senesi N (Ed.), interaction between soil particles and microorganism. John Wiley \& Sons, New York, pp: 85-131.

[4] Baldock, J. A. (2002). Interactions between organic materials and microorganisms with materials in the stabilization of soil structure. In: Huang PM, Bollag JM, Senesi N (Eds.), Interactions between soil particles and microorganism. John Wiley \& Son, New York, pp:85-131.

[5] Belachew T. And Abera Y. (2010) assesment of soil fertility status with depth in wheat growing highlands of Southeast Ethiopia. World Journal of Agricultural Sciences, 6(5):525-531.

[6] Boularhah A. Schwartz C, Bitton G,Morel JL (2006a) Heavy metals contamination from mining sites in south Morocco: 1. Use of biotest to assess metal toxicity of tailing and soils. Chemosphere 63(5): 802-810.

[7] Coppin, N. J., and Bradshaw, A. D. (1982). The establishment of vegetation in quarries and open pit non-metal mines. Mining Journal Books, London, 112 p.

[8] Crowley D. (2008). Impact of metals and metalloids on soil microbial diversity and ecosystem function. 5th International Symposium ISMOM 2008-November 24th-28th, 2008-Puco'n, Chile.

[9] Donahue, R. I., Miller, R. W., and Shickluna, J. C. (1990). Soil: An Introduction to soils and plant growth (5th ed). Practice-Hall, 234p.

[10] Don, A., Schulze, E.D. (2008). Controls on fluxes and export of dissolved organic carbon in grasslands with contrasting soil types. Biogeochemistry. 91, 117-131.

[11] Garcia-Lorenzo ML, Martinez-Sanchez, perez-Sirvent C, Molina J (2009) Ecotoxicologycal evaluation for the screening of areas polluted by mining activities. Ecotoxicology 18:1077-1086.

[12] Gitt, M. J. And Dollhopf, D. J. (1991). Coal waste reclamation using automated weathering to predict lime requirment. Journal Environmental Quality 20, 285-288.

[13] Ghosh, A. B., Bajaj, J. C., Hassan, R., and Singh, D. (1983). Soil and watertesting methods. A laboratory manual, IARI, New Delhi, 31-36.

[14] Gould, A. B., Hendrix, J. W., and Ferriss, R. S. (1996). Relationship of mycorrhizal activity of time following reclamation of surface mine land in western Kentucky. I Propagule and spore population densities. Canadian Journal Botany 74, 247-261.

[15] Hakim, N., M. Y Nyakpa., A. M. Lubis., S.G. Nugraha, G.B. Hong., H. Bailey (1986) Dasar-dasar Ilmu Tanah (Basic of Soil Science). Published by Lampung University, Lampung.

[16] Ismail, S.M., Ozawa, K. (2007) Improvement of crop yield, soil moisture distribution and water use efficiency in sandy soils by clay application. Appl. Clay Sci. 37, 81-89.

[17] Kaiser, K., Zech, W. (2000). Dissolved organic matter sorption by mineralmconstituents of subsoil clay fractions. J. Plant. Nutr. Soil Sci. 163, 531-535.

[18] Kavamura, V. N., and esposito, E. (2010). Biotecnological strategies applied to the decontamination of soil polluted with heavy metals. Biotechnology Advances 28, 61-69. 
[19] Lone, M. I., He, Z. I., Stoffella, P. J., and Yang, X. (2008). Phytoremediation of heavy metal polluted soild and water: Progress and perspectives. Journal of Zhejiang University SCIENCE B9(3), 210-220.

[20] Maiti, S. K., and Ghose, M. K. (2005). Ecological restoration of acidic coal mine overburden dumps- an Indian case studi. Land Contamination and Reclamation 13(4), 361-369.

[21] McKissock, I., Gilkes, R.J., Walker, E.L. (2002) The reduction of water repellency by added clay is influenced by clay and soil properties. Appl. Clay Sci. 20, 225-241.

[22] Muhammad S, Tahir Shah M, Khan S (2011) Heavy metal concentrations in soil and wild plants growing around $\mathrm{Pb}-\mathrm{Zn}$ sulfite terrain in the Kohistan region, northern Pakistan. Microchem J 99:67-75.

[23] Roper, M.M., Smith, N.A. (1991) Straw decomposition and nitrogenase activity $\left(\mathrm{C}_{2} \mathrm{H}_{2}\right.$ reduction $)$ by freeliving microorganisms from soil-effects of $\mathrm{pH}$ and clay content. Soil Biol. Biochem. 23, 275-283.

[24] Sanchez, P.A. (1993) Sifat dan pengelolaan tanah tropika (Characteristic and management of tropical soil). Publisher of ITB, Bandung.

[25] Sheoran, A. S., Sheoran, V., and Poonia, P. (2008). Rehabilitation of mine degraded land by metallophytes, Mining Engineers Journal 10 (3), 11-16.

[26] Sheron, V., Sheron A. S., Poonia P. (2010). Soil Reclamation of abondoned mine land by revegetation: a review. International Journal of Soil, Sediment and Water. Vol. 3. Iss.2. 13 ISSN: 1940-3259.

[27] Singh, A. N., Raghubanshi, A.S., and Singh, J. S. (2002) Plantations as a tool for mine spoil restoration current science 82(12), 1436-1441.

[28] Torres KC, Johnson ML (2001) Bioaccumulation of metals in plants, arthropods, and mice at a seasonal wetlant. Environ Toxicol Cham 20(11):2617-2626.

[29] Tufaila M., Alam S. (2014) Karakteristik tanah dan evaluasi untuk pengembangan tanaman padi sawah di Kecamatan Oheo Kabupaten Konawe Utara (Soil characteristics and evaluation for the development of wetland rice crops in Oheo Sub-District, Konawe Utara District). Journal of AGRIFLUS, vol. 24 no. 02, 2014.

[30] Widodo, R.A. (2006) Evaluasi kesuburan tanah pada lahan tanaman sayuran di Desa Sewukan, Kecamatan Dukun Kabupaten Magelang (Evaluation of soil fertility on vegetable plant land in Sewukan Village, District of Magelang. J. Tanah dan Air (Journal of soil and water), 7(2): 142-150.

[31] Wong, M. H., 2003. Ecological restoration of mine degraded soils, with emphasis on metal contaminated soils. Chemosphere 50, 775-780.

[32] Zotarelli, L., Scholberg, J.M., Dukes, M.D., Munoz Carpena, R., 2007. Monitoring of nitrate leaching in sandy soils: comparison of three methods. J. Environ. Qual. 36, 953-962. 